\title{
The impact of irrigation on yield of alfalfa and soil chemical properties of saline-sodic soils
}

\author{
Hongtao Yang ${ }^{1,2}$, Fenghua An ${ }^{2}$, Fan Yang ${ }^{2}$, Zhichun Wang ${ }^{\text {Corresp. } 2}$ \\ 1 University of Chinese Academy of Sciences, Beijing, China \\ 2 Northeast Insitute of Geography and Agroecology, Chinese Academy of Sciences, Changchun city, Jilin Province, China \\ Corresponding Author: Zhichun Wang \\ Email address: wangzhichu@iga.ac.cn
}

Background. Forage production in the saline-sodic soil of the western Songnen Plain Northeast China depends on irrigation. Therefore, the water use efficiency (WUE) and soil chemical properties are key factors in the overall forage productivity in this water scarce region. Improving forage yield, WUE, and soil properties under irrigation are very important for food and ecological security in this water-deficient region. Additionally, a suitable irrigation schedule for this region is necessary.

Methods. A field experiment was conducted between 2015 and 2018 to evaluate the effects of irrigation on artificial grassland productivity and the changes in soil chemical properties as well as to plan a reliable irrigation schedule for the western Songnen Plain. Eight irrigation treatments were designed, which depended on the three growth stages of alfalfa. The shoot height (SH), the chlorophyll content (SPAD), the dry yield (DM), the ratio of stem to leaves (SLR), the WUE, the changes in the chemical properties of the soil, and precipitation and evaporation were investigated.

Results. The SH, DM, WUE, and SLR were significantly increased by irrigation $(P<0.01)$. However, the SPAD resulting from irrigation was not significantly higher than the SPAD of CK $(P<0.05)$. In addition, the soil chemical properties at the depth of $0-100 \mathrm{~cm}$ were significantly decreased by irrigation $(P<0.5)$. For example, the soil EC, SAR, and TA were reduced $182-345 \mu \mathrm{S} \mathrm{cm}^{-1}, 8.95-9.00\left(\mathrm{mmol}_{\mathrm{d}} / \mathrm{L}\right)^{1 / 2}$, and 3.29-4.65 $\mathrm{mmol}_{\mathrm{c}} \mathrm{L}^{-1}$ by different irrigation treatments, respectively. Finally, considering the highest WUE of $\mathrm{I5}(2.50$ $\left.\mathrm{kg} \mathrm{m}^{-3}\right)$, relative high DM of $\mathrm{I5}\left(787.00 \mathrm{~g} \mathrm{~m}^{-2}\right)$, the precipitation, the evaporation, the water resources, and the changes of the soil's chemical properties, $236.50 \mathrm{~mm}$ of irrigation water was recommended at the branching stage of alfalfa for the eastern Songnen Plain, Northeast China. 
1 The impact of irrigation on yield of alfalfa and soil 2 chemical properties of saline-sodic soils

3

4 Hongtao Yang ${ }^{1,2}$, Fenghua $\mathrm{An}^{2}$, Fan Yang ${ }^{2}$, Zhichun Wang,**

51 University of Chinese Academy of Sciences, Beijing 100049, (China)

62 Northeast Institute of Geography and Agroecology, Chinese Academy of Sciences, Changchun

7 130102, (China)

8 Corresponding Author:

9 Zhichun Wang

10 Shengbei Street No. 4888, Changchun city, Jilin Province, 130102, China

11 Email address: wangzhichun@iga.ac.cn 
12 The impact of irrigation on yield of alfalfa and soil

13 chemical properties of saline-sodic soils

14 Abstract

Background. Forage production in the saline-sodic soil of the western Songnen Plain Northeast

properties are key factors in the overall forage productivity in this water scarce region. Improving forage yield, WUE, and soil properties under irrigation are very important for food and ecological security in this water-deficient region. Additionally, a suitable irrigation schedule for this region is necessary.

Methods. A field experiment was conducted between 2015 and 2018 to evaluate the effects of irrigation on artificial grassland productivity and the changes in soil chemical properties as well as to plan a reliable irrigation schedule for the western Songnen Plain. Eight irrigation treatments were designed, which depended on the three growth stages of alfalfa. The shoot height (SH), the chlorophyll content (SPAD), the dry yield (DM), the ratio of stem to leaves (SLR), the WUE, the changes in the chemical properties of the soil, and precipitation and evaporation were investigated.

Results. The SH, DM, WUE, and SLR were significantly increased by irrigation $(\mathrm{P}<0.01)$. However, the SPAD resulting from irrigation was not significantly higher than the SPAD of CK $(\mathrm{P}<0.05)$. In addition, the soil chemical properties at the depth of $0-100 \mathrm{~cm}$ were significantly decreased by irrigation $(\mathrm{P}<0.5)$. For example, the soil EC, SAR, and TA were reduced 182-345 $\mu \mathrm{S} \mathrm{cm}^{-1}, 8.95-9.00\left(\mathrm{mmol}_{\mathrm{c}} / \mathrm{L}\right)^{1 / 2}$, and 3.29-4.65 $\mathrm{mmol}_{\mathrm{c}} \mathrm{L}^{-1}$ by different irrigation treatments, respectively. Finally, considering the highest WUE of I5 $\left(2.50 \mathrm{~kg} \mathrm{~m}^{-3}\right)$, relative high DM of I5 $\left(787.00 \mathrm{~g} \mathrm{~m}^{-2}\right)$, the precipitation, the evaporation, the water resources, and the changes of the soil's chemical properties, $236.50 \mathrm{~mm}$ of irrigation water was recommended at the branching stage of alfalfa for the eastern Songnen Plain, Northeast China.

Abbreviations: $\mathrm{ET}_{0}$, the reference evapotranspiration, $\mathrm{mm} ; \mathrm{ET}_{\mathrm{a}}$, the actual evapotranspiration, $\mathrm{mm}$; Y, actual yield, $\mathrm{kg} \mathrm{ha}^{-1} ; \mathrm{Y}_{\mathrm{m}}$, maximum or potential grain yield with water not limiting production, $\mathrm{kg}$ $\mathrm{ha}^{-1} ; \mathrm{ET}_{\mathrm{i}}$, actual evapotranspiration in growth stage $\mathrm{i}, \mathrm{mm} ; \mathrm{ET}_{\mathrm{mi}}$, maximum or potential evapotranspiration in growth stage $\mathrm{i}, \mathrm{mm} ; \lambda_{\mathrm{i}}$, water sensitive index in growth stage $\mathrm{i}$; $\mathrm{I}$, the amount of irrigation water, $\mathrm{mm}$; $\mathrm{P}$, precipitation, $\mathrm{mm}$; $\mathrm{D}$, the amount of drainage water, $\mathrm{mm} ; \mathrm{R}$, amount of runoff, $\mathrm{mm} ; \Delta \mathrm{W}$, changes in the soil water content, $\mathrm{mm}$; DM, dry yield of alfalfa, $\mathrm{g} \mathrm{m}^{-2}$; $\mathrm{SH}$, shoot height, $\mathrm{cm}$; SPAD, the content of chlorophyll (SPAD); SLR, ratio of stem to leaves, \%; C, design irrigation coefficient; $\mathrm{K}_{\mathrm{c}}$, crop coefficient; WUE, water use efficiency, $\mathrm{kg} \mathrm{m}^{-3}$; EC, soil electrical conductivity, $\mu \mathrm{S} \mathrm{cm}^{-1}$; SAR, sodium absorption ratio, $\left(\mathrm{mmol}_{\mathrm{c}} / \mathrm{L}\right)^{1 / 2}$; TA, total alkalization, $\mathrm{mmol}_{\mathrm{c}} \mathrm{L}^{-1}$;

\section{Introduction}

Numerous environmental factors are potentially detrimental to plants (Breusegem et al., 2001). Soil salinity-sodicity is a major environmental factor which limits the plant growth and productivity in the irrigated sections of arid and semi-arid regions (Qadir et al., 2008; Koca et al., 2007; Qadir et al., 2001), including the Songnen Plain, Northeast China, where the precipitation cannot maintain a regular infiltration 
51 of water through the soil due to the soil's salinity-sodicity. The growth, development, and differentiation

52 of plants growing on saline-sodic lands are generally limited by soil salinization and alkalization; this leads

53 to a decrease in the productivity of the plants. Irrigation is important to maintain a higher forage yield of 54 alfalfa in arid and semi-arid regions (Guo et al., 2007).

Saline-sodic soils cover $5.60 \times 10^{8}$ ha worldwide (Tanji, 1990). Such soils are commonly found in arid and semi-arid regions and are characterized by both a high salt content and excessive $\mathrm{Na}^{+}$, which causes damage to the soil structure and a reduction in soil infiltration rate and fertility (Qadir \& Schubert, 2002; Qadir et al., 2005). It has been reported that the saturation hydraulic conductivity of saline-sodic soils is only 0.02-0.22 $\mathrm{mm} \mathrm{d}^{-1}$ (Chi \& Wang, 2010), and the infiltration rate decreases quickly after 10 min of irrigation and tends to $0 \mathrm{~mm} \mathrm{~d}^{-1}$ after $15 \mathrm{~min}$ of irrigation (Wang et al., 2004). In addition, the soil $\mathrm{pH}$ of saline-sodic soils ranges from 8.5 to 10.5 with $30 \%$ to over $70 \%$ of exchangeable sodium percentage (ESP) (Li et al., 2006). Today, water shortages and soil salinity-sodicity are considered to be the greatest factors that limit plant survival and growth (Bandeoğlu et al., 2004; Shi \& Wang, 2005). Moreover, the movement of salts follows the soil water flow, which causes a water deficit or low effectiveness of the soil water.

Alfalfa (Medicago sativa L.), is a C3 plant and one of the most important perennial legume forages around the world because of its good nutritional forage quality for livestock husbandry and its ability to improve soil fertility (Guo et al., 2005; Dincă et al., 2017). However, it is generally accepted that alfalfa is a high water requirement species compared with other crops due to its high yield and long growing season (Bauder et al., 1992). Numerous studies have indicated that the seasonal evapotranspiration of alfalfa is approximately 700-1600 mm depending on the climate and growing period (Sahin \& Hanay, 1996; FAO, 2002). The goals of food security and food sufficiency in the next decades for the western Songnen Plain in northeastern China are linked to the increased availability of irrigation water and high soil fertility. This will increase the pressure on the natural resources of soil and water, considering that the region is characterized by water scarcity and a wide area of saline-sodic soils. Water shortage and soil salinity can be alleviated by enhancing the WUE and ameliorating the saline-sodic soils. The Songnen Plain is challenged by a higher rate of evaporation reaching 1700-1900 mm compared to an annual precipitation of $370-400 \mathrm{~mm}, 80 \%$ of which occurs in July and August (Chi \& Wang, 2010). There is a significant difference between the annual precipitation and the water demand of alfalfa. Thus, irrigation is crucial for alfalfa to gain maximum forage yield in this region.

Irrigation is widely used to maintain a higher forage yield of alfalfa in arid and semi-arid regions (Guo et al., 2007). However, it is difficult to schedule the irrigation since it would require complex economic and environmental analysis to determine the optimal irrigation operation. Previous studies on artificial grasslands have mainly focused on the comparison of irrigation modes and water use efficiency of alfalfa (Grimes et al. 1992; Estill et al., 1993; Potters et al., 2007; Kuslu et al., 2010; Singh et al., 2010). However, 
there is lack of information on the effects of different irrigation schedules on artificial grassland productivity, saline-sodic soil chemical property changes, and suitable water management for the western Songnen Plain, Northeast China.

The objectives of this study were to answer the following questions: 1) which irrigation schedule would be optimal for promoting the productivity of artificial grassland of alfalfa in the western Songnen Plain? 2) How would the irrigation schedules affect the yield of alfalfa and the soil chemical properties?

\section{Materials \& Methods Study site and plant material}

The experiment site $\left(\mathrm{N} 45^{\circ} 34^{\prime} 36^{\prime \prime}-45^{\circ} 34^{\prime} 29^{\prime \prime}\right.$, E $\left.123^{\circ} 2^{\prime} 24^{\prime \prime}-123^{\circ} 2^{\prime} 47^{\prime \prime}\right)$ was located $15 \mathrm{~km}$ east of Baicheng City, Jilin Province, China. The climate of the study site is a temperate continental monsoon climate with an annual precipitation of $370-400 \mathrm{~mm}$ and the annual evaporation more than $1500 \mathrm{~mm}$ (Figure 1, data from the Meteorological Bureau of Baicheng City, Jilin Province).

Figure 1 The monthly precipitation and evaporation of the study site (recorded from 2008.1.1 to 2018.7.31)

The field experiment was conducted from September 2015 to July 2018 on a saline-alkali artificial grassland, which was established in the spring of 2009 by incorporating $20 \mathrm{~cm}$ of sandy soil into a degraded natural grassland. The Alfalfa cultivar of Gongnong No. 1 of Medicago sativa L. cv. was used as the plant material in this experiment and the alfalfa was harvested in July and October every year. The irrigation water was supplied from a local well (Depth $>100 \mathrm{~m}, \mathrm{pH}=7.5, \mathrm{EC}=50 \mu \mathrm{S} \mathrm{cm}^{-1}$ ).

The backgrounds of the physico-chemical properties of the soil (at depth of 0-100 cm) are shown in Table 1.

Table 1 The backgrounds of soil physico-chemical properties

Note, EC, electrical conductivity; SAR, sodium absorption ratio; TA, total alkalinity

The average soil bulk density (0-100) was $1.59 \mathrm{~g} \mathrm{~cm}^{-3}$ and there was a wide range for the soil $\mathrm{pH}(8.52-$ 10.45). The soil electrical conductivity (EC) averaged $\geq 200 \mu \mathrm{S} \mathrm{cm}^{-1}$. The soil at the depth of $0-20 \mathrm{~cm}$ and 20-100 cm were classified as sandy soil and loam, respectively, according to the international soil system.

\section{Experimental design}

The spatial distribution of the experiment plots followed a randomized block design (Figure 2). Each plot was $5 \mathrm{~m} \times 4 \mathrm{~m}=20 \mathrm{~m}^{2}$.

Figure 2 The distribution and area of experiment plots

The alfalfa on the western Songnen Plain was harvested at flower stage, thus, there were eight irrigation treatments based on the three growing stages of alfalfa with three replications (Table 2).

The irrigation water amount (I, mm) was calculated as following:

$$
\mathrm{I}=\mathrm{C} \times \mathrm{ET}_{\mathrm{c}}
$$


119

120

121

122

123

124

125

126

127

128

129

130

131

132

133

134

135

136

137

138

139

140

141

142

143

144

145

146

147

148

150

151

152

$$
\begin{gathered}
\mathrm{ET}_{\mathrm{c}}=\mathrm{ET}_{0} \times \mathrm{Kc}=\mathrm{P}+\mathrm{I}-\mathrm{D}-\mathrm{R} \pm \Delta \mathrm{W} \\
\boldsymbol{E} \boldsymbol{T}_{0}=\frac{0.408 \Delta(\mathrm{Rn}-\mathrm{G})+\gamma \frac{900}{\boldsymbol{T}+273} \mu_{2}\left(\mathrm{e}_{\mathrm{s}}-\mathrm{e}_{\mathrm{a}}\right)}{\Delta+\gamma\left(1+0.34 \mu_{2}\right)}
\end{gathered}
$$

$\mathrm{ET}_{\mathrm{c}}$, alfalfa evapotranspiration or crop water use, $\mathrm{mm}$; C, design irrigation coefficient, $30 \%, 60 \%$, $90 \%$, and $0 \%$ in this study; Kc, crop coefficient, 0.83 (Gulik, 2001); $\mathrm{ET}_{0}$, reference ET for alfalfa (mm), calculated by the Penman-Monteith method (Allen et al., 1998); Rn, net radiation, $\mathrm{MJ} \mathrm{m}^{-2} \mathrm{~d}^{-1}$; G, soil heat flux density, $\mathrm{MJ} \mathrm{m}^{-2} \mathrm{~d}^{-1} ; \mathrm{T}$, mean daily air temperature at $2 \mathrm{~m}$ height, ${ }^{\circ} \mathrm{C} ; \mu_{2}$, wind speed at $2 \mathrm{~m}$ height, $\mathrm{m}$ $\mathrm{s}^{-1} ; \mathrm{e}_{\mathrm{s}}$, saturator vapor pressure, $\mathrm{kPa}$; $\mathrm{e}_{\mathrm{a}}$, the actual vapor pressure, $\mathrm{kPa} ; \Delta$, slope of the vapor pressure curve, $\mathrm{kPa}{ }^{\circ} \mathrm{C}^{-1} ; \gamma$, psychometric constant, $\mathrm{kPa}^{\circ} \mathrm{C}^{-1}$;

Table 2 The experiment design

Note, $\mathrm{C}$, designed irrigation coefficient; $\mathrm{R}$, regreen stage, $\mathrm{B}$, branch sage, $\mathrm{F}$, flower stage; $\mathrm{ET}_{1}$, the mean reference $\mathrm{ET}$ for alfalfa regreen stage, $\mathrm{mm} ; \mathrm{ET}_{2}$, the mean reference $\mathrm{ET}$ for alfalfa branch stage, $\mathrm{mm} ; \mathrm{ET}_{3}$, the mean reference $\mathrm{ET}$ for alfalfa flower stage, $\mathrm{mm}$;

\section{Data collection}

The relative chlorophyll content (SPAD) in each plant was determined using a SPAD-502 Chlorophyll Meter (Minolta Co. Ltd., Osska, Japan). The SPAD was measured every week following the beginning of the regreen stage of alfalfa. The SPAD of each alfalfa was measured five times and then the mean values of SPAD were calculated. Five alfalfa stems were selected randomly from each plot for measuring the shoot height using a ruler from the base of stem to the end.

Dry yields $(\mathrm{DM})$ were measured by harvesting a $1.00 \mathrm{~m} \times 1.00 \mathrm{~m}$ quadrat from the center of each plot when the alfalfa reached 50-flower. Samples were air-dried in a repository. The DM was calculated by the $1^{\text {st }}$ and the $2^{\text {nd }}$ harvest of alfalfa dry yield.

Each subsample of alfalfa was separated into the leaf and stem fraction for measuring the ratio of stem to leaves (SLR). The SLR was calculated as the average of the $1^{\text {st }}$ and $2^{\text {nd }}$ harvest of alfalfa.

The soil water balance and alfalfa evapotranspiration (ETc) were calculated using following equation (Carter and Sheaffer, 1983):

44

45

46

(1)

out of root zone, $\mathrm{mm}$; $\mathrm{R}$, surface runoff, $\mathrm{mm} ; \Delta \mathrm{W}$, change in soil water storage, $\mathrm{mm}$;

$\mathrm{ET}_{\mathrm{c}}$, evapotranspiration, $\mathrm{mm}$; $\mathrm{P}$, precipitation, $\mathrm{mm}$; I, irrigation amount, $\mathrm{mm}$; $\mathrm{D}$, downward drainage

Drainage (D) below the root zone was assumed to be zero since water applied with each irrigation was less than or equal to the water deficit in the $1 \mathrm{~m}$ soil profile of the fully irrigated treatment. Runoff $(\mathrm{R})$ was considered zero because the experimental plots were surrounded by $0.15 \mathrm{~m}$ high and $20 \mathrm{~m}$ long plastic levees around its perimeter and the basin were meticulously prepared to be level.

The meteorological data from 2015 to 2018, including precipitation (P), were collected by the meteorological station (HOBO U30 Weather station, Onset Computer Corporation, USA). The actual 
153

154

155

156

158

159

160

161

162

163

164

165

166

167

168

169

170

171

172

173

174

175

176

177

178

179

180

181

182

183

amount of irrigation ( $\mathrm{I}, \mathrm{mm}$ ) was recorded by the water meter set up in each plot. Neutron probe tubes were installed for measuring the $\Delta \mathrm{W}$ weekly at the depth of $0-100 \mathrm{~cm}$.

The irrigation should be slight and applied frequently at every growth stage to avoid water-logging the plot. Water use efficiency (WUE, $\mathrm{kg} \mathrm{m}^{-3}$ ) was calculated according to Equation 2 (Ojedaa et al., 2018):

$$
\begin{aligned}
& \mathrm{WUE}=\mathrm{Y} / \mathrm{ETc} \\
& \mathrm{Y}, \text { yield, } \mathrm{g} \mathrm{m}^{-2} \text {; }
\end{aligned}
$$

The water table significantly declined following the extreme drought from 2015 to 2017, and large areas of new paddy fields were developed nearby. Thus, hydraulic pressure was too low to support all the plots equally. This may have caused insignificant differences in the actual water consumption among the different irrigation treatments.

The alfalfa water sensitive indexes of different growth stages were calculated as (Jensen, 1968):

$$
\frac{Y}{Y_{\mathbf{m}}}=\prod_{i=1}^{\mathbf{n}}\left(\frac{E T_{i}}{E T_{m i}}\right)^{\lambda_{i}}
$$

$\mathrm{n}$, stage number of alfalfa; i, serial number of alfalfa growth stages; $\mathrm{Y}$, actual yield, $\mathrm{kg} \mathrm{ha}^{-1} ; \mathrm{Y}_{\mathrm{m}}$, maximum or potential grain yield with water not limiting production, $\mathrm{kg} \mathrm{ha}^{-1} ; \mathrm{ET}_{\mathrm{i}}$, actual evapotranspiration in growth stage $\mathrm{i}, \mathrm{mm} ; \mathrm{ET}_{\mathrm{mi}}$, maximum or potential evapotranspiration in growth stage $\mathrm{i}, \mathrm{mm}$; $\lambda_{\mathrm{i}}$, water sensitive index in growth stage $\mathrm{i}$;

Soil samples were collected with a soil auger at a depth of 0-100 cm in September 2015 and October 2017 in order to measure for soil chemical properties, such as soil pH, soil electrical conductivity (EC), sodium absorption ratio (SAR), and total alkalization (TA).

The collected soil samples were air-dried, mixed, sieved through a 2-mm sieve, and then analyzed according to the methods described by the USDA (1954). Soil $\mathrm{pH}$ and EC were measured in a soil-water suspension with a 1:5 soil/water ratio, using a pH and EC meter (LeiCi Co. Ltd., Shanghai, China, and specifications of the glass electrodes were DJS-1C and PHSJ-3F, respectively). The $\mathrm{K}^{+}$and $\mathrm{Na}^{+}$ concentrations from the soil-water extracts were analyzed by using flame photometry (Shanghai Precision Co. Ltd., China), whereas the concentrations of $\mathrm{Ca}^{2+}$ and $\mathrm{Mg}^{2+}$ were determined by atomic absorption spectrometry (Haiguang GGX605, Shanghai, China). The SAR and TA were calculated by the equations below (Wang et al., 2018).

$$
\boldsymbol{S} \boldsymbol{A} \boldsymbol{R}=\frac{\left[\mathrm{Na}^{+}\right]}{\sqrt{\left[\mathrm{Ca}^{2+}+\mathrm{Mg}^{2+}\right] / 2}}
$$

$$
\mathrm{TA}=\left[\mathrm{CO}_{3}{ }^{2-}\right]+\left[\mathrm{HCO}_{3}^{-}\right]
$$

The differences of soil pH, EC, SAR, and TA at 2015 and 2017 were calculated for representing the changes in the soil chemical properties. 
184

185

186

187

188

189

190

191

192

193

194

195

196

197

198

199

200

201

202

203

204

205

206

207

208

209

210

211

212

213

214

215

216

217

218

$$
\begin{gathered}
\Delta \mathrm{pH}=\mathrm{pH}_{2015}-\mathrm{pH}_{2017} \\
\Delta \mathrm{EC}=\mathrm{EC}_{2015}-\mathrm{EC}_{2017} \\
\Delta \mathrm{SAR}=\mathrm{SAR}_{2015}-\mathrm{SAR}_{2017} \\
\Delta \mathrm{TA}=\mathrm{TA}_{2015}-\mathrm{TA}_{2017}
\end{gathered}
$$

\section{Data analysis}

For each soil sample, one-way ANOVA was performed on SLR, DM, SH, SPAD, and WUE using SPSS $(\mathrm{P}<0.05)$ (Version 20.0, IBM). Multiple linear regression was conducted to determine the relationship between the actual alfalfa yield and the predictable alfalfa yield.

Origin 8.0 (OriginLab Corporation, Northampton, MA, USA) was employed for the figuring.

\section{Results}

\section{Precipitation and evaporation during the growing season}

The results of the monthly precipitation and evaporation during the alfalfa growth periods from 2015 to 2018 (during the April and October) were shown in Figure 2.

\section{Figure 3 The monthly precipitation and evaporation during the growing season of alfalfa (P, precipitation, mm;} E, evaporation, $\mathrm{mm}$ )

The total precipitation and evaporation during the alfalfa growth season were $399.25 \mathrm{~mm}$ and 1020.01 $\mathrm{mm}$, respectively (Figure 3). The highest monthly precipitation was $91.75 \mathrm{~mm}$, which was observed in July, and the lowest monthly precipitation was $7.15 \mathrm{~mm}$, which was observed in April. The highest monthly evaporation was $205.60 \mathrm{~mm}$ (April) which was double the monthly evaporation of October (101.67 $\mathrm{mm})$.

\section{The bio-characteristics of alfalfa under different treatments}

The shoot height (SH, cm), SPAD, dry yield (DM, $\mathrm{g} \mathrm{m}^{-2}$ ), and the SLR of different treatments were shown in the Table 3.

\section{Table 3 The DM, SH, SPAD, and SLR of alfalfa under different treatments}

Note, SLR, mass ratio of stems to leaves; DM, dry yield, $\mathrm{g} \mathrm{m}^{-2}$; SH, shoot height of alfalfa, $\mathrm{cm}$; I1, irrigate at regreen and branch stages; I2, irrigate at branch and anthesis stages; I3, irrigate at regreen and anthesis stages; I4, irrigate at branch stage; I5, irrigate at branch stage; I6, irrigate at anthesis stage; I7, irrigate at regreen, branch and anthesis stages; CK, no irrigation;

It was clear that the alfalfa DM, SLR, and SH were significantly $(\mathrm{P}<0.05)$ influenced by irrigation in the western Songnen Plain. The DMs of the irrigated plots were $455.26 \%-1393.86 \%$ heavier than the DM of CK. The SH of irrigation treatments were $79.04 \%-124.61 \%$ higher than the SH of CK. In addition, SLRs of irrigation treatments were $1.87 \%$ higher than the SLR of CK. Furthermore, irrigation treatment enhanced the chlorophyll concentration more than the $\mathrm{CK}$; however, there were no significant differences $(\mathrm{P}>0.05)$.

The DMs of alfalfa irrigated at only one growth stage was significantly $(\mathrm{P}<0.05)$ lower than the DMs of alfalfa irrigated at two growth stages. The DM of I2 reached up to $980 \mathrm{~g} \mathrm{~m}^{-2}$, which was the highest yield among the deficit irrigation treatments, which was followed by I1 $\left(953.33 \mathrm{~g} \mathrm{~m}^{-2}\right)$. The highest DM of alfalfa 
219 irrigated at one growth stage was observed at the I5 treatment $\left(786.67 \mathrm{~g} \mathrm{~m}^{-2}\right)$. Evidence observed in this 220 study showed that the effect of irrigation treatments on SLR was not significant $(\mathrm{P}>0.05)$. The SLRs of 221 I1, I4, and I5 were decreased and the SLRs of I2, I3, I6, and I7 were increased by irrigation. The highest 222 SLR was 2.62, which was observed at full irrigation treatment (I7) and then followed by SLR of I2 (2.24) 223 and I2 (2.2.4). The SHs of eight irrigation treatments ranged from $55.11 \mathrm{~cm}$ to $123.78 \mathrm{~cm}$. Results of SH 224 showed that I7, which was irrigated at regreen, branch, and flower stages, performed the best on the increase 225 of the alfalfa shoot height, followed by the I2 and I6 treatments. The values of SPAD increased from 53.33 to 64.87 among the eight irrigation treatments. Maximum SPAD (64.87) was observed from the I7 treatment, and the minimum SPAD (53.33) from CK.

228

229

230

231

232

233

234

235

236

237

238

239

240

241

242

243

244

245

246

247

248

249

250

251

252

\section{The actual water consumption and water use efficiency}

The total amount of water applied to alfalfa ranged from $85.00 \mathrm{~mm}$ to $755.00 \mathrm{~mm}$ in different irrigation treatments (Figure 4). The actual water consumption of I1, I2, and I3 were $390.18 \mathrm{~mm}, 410.82 \mathrm{~mm}$, and $386.59 \mathrm{~mm}$, respectively. Additionally, the actual water consumption of I4, I5, and I6 was $305.46 \mathrm{~mm}$, $314.48 \mathrm{~mm}$, and $288.08 \mathrm{~mm}$, respectively. Furthermore, the $\mathrm{I} 7$ consumed $733.00 \mathrm{~mm}$ of water. The lowest water consumption was observed in the $\mathrm{CK}$ treatment $(85.49 \mathrm{~mm})$.

The WUE of 7 treatments with irrigation ranged from $1.33 \mathrm{~kg} \mathrm{~m}^{-3}$ to $2.50 \mathrm{~kg} \mathrm{~m}^{-3}$ and were significantly higher than the WUE of CK $(\mathrm{P}<0.05)$, however, no differences among the WUEs of irrigation treatments were found $(\mathrm{P}<0.05)$. The lowest WUE $\left(1.33 \mathrm{~kg} \mathrm{~m}^{-3}\right)$ was observed at $\mathrm{CK}$. There were no significant differences in WUE between the I1 $\left(2.47 \mathrm{~kg} \mathrm{~m}^{-3}\right)$, I2 $\left(2.42 \mathrm{~kg} \mathrm{~m}^{-3}\right)$, and I3 $\left(2.28 \mathrm{~kg} \mathrm{~m}^{-3}\right)$, which were irrigated at two growth stages of alfalfa. Compared to I4 and I6, which were irrigated at one growth stage of alfalfa, I5 has reached the highest WUE $\left(2.50 \mathrm{~kg} \mathrm{~m}^{-3}\right)$. This might imply that irrigation at the branch stage has an important influence on the WUE of alfalfa.

Figure 4 The WUE and water consumption of different treatments $(\mathrm{P}<0.05)$

\section{Irrigation schedule for western Songnen Plain}

The water insensitive indexes of alfalfa at the regreen, branch, and flower stages were shown in Figure 5 below.

Figure 5 The water sensitive index of alfalfa (R, regreen period; B, branch period; A, flower period)

The Figure 5 showed that the water sensitive index (WSI) of the branch period was significantly higher $(\mathrm{P}<0.05)$ than the WSIs of the regreen and flower periods. In addition, there was no significant $(\mathrm{P}<0.05)$ difference between the WSI of regreen and flower.

The water production function of alfalfa in the western Songnen Plain was determined with $\lambda_{1}, \lambda_{2}$ and $\lambda_{3}$ these was shown in Figure 5. Then the water production function of alfalfa in the Songnen Plain was displayed in Equation 13. 


$$
\frac{Y}{Y_{\mathbf{m}}}=\left(\frac{E T_{1}}{E T_{m 1}}\right)^{0.5202} \times\left(\frac{E T_{2}}{E T_{m 2}}\right)^{1.2393} \times\left(\frac{E T_{3}}{E T_{m 3}}\right)^{0.6313}
$$

254

255

256

257

258

259

260

261

262

263

264

265

266

267

268

269

270

271

272

273

274

275

276

277

278

279

280

281

282

283

284

285

286

Figure 6 Actual and simulated of alfalfa yield and the relations to the irrigation amount (DM-J, alfalfa yield simulated by Jensen Model, $\mathrm{t}$ ha $^{-1}$; DM-A, actual alfalfa yield, $\mathrm{t} \mathrm{ha}^{-1}$ )

The determination correlation coefficient $(\mathrm{r}=0.71)$ between the simulated alfalfa dry yield and the amount of irrigation water was 0.71 , which was in the critical coefficient between the simulated alfalfa dry yield and the amount of irrigation water (0.30-0.93). Thus, the Jensen model was reliable for the western Songnen Plain, Northeast China for irrigation scheduling. The simulated yield obtain from the Jensen model of the western Songnen Plain was lower than the actual yield (Figure 6). However, the simulated alfalfa dry yield would be closer to the actual alfalfa dry yield when the amount of irrigation water reached at 150.00$350.00 \mathrm{~mm}$.

\section{Figure 7 The relation between amount of irrigation and actual alfalfa yield}

The relationship between the alfalfa yield and the amount of irrigation on the artificial grassland in the western Songnen Plain can be simulated with the cubic curve $\left(y=125.188+3.449 x+0.002 \mathrm{x}^{2}-10^{-6} \mathrm{x}^{3}\right.$, $\left.650>\mathrm{x}>0, \mathrm{R}^{2}=0.91, \mathrm{~F}=65.61>\mathrm{F} 0.01(3,20)=4.94\right)$ (Figure 7). Alfalfa yield could rapid increase coupled with the amount of irrigation increase when less than $650 \mathrm{~mm}$ water was supplied.

Based on the data above, $236.50 \mathrm{~mm}$ of irrigation water was recommended at the branch stage of alfalfa for the eastern Songnen Plain, Northeast China.

\section{Effects of irrigation on soil chemical properties}

Results of changes in soil chemical properties after two-years of irrigation were shown in the figures below.
Figure 8 The soil pH changes at depth of 0-100 cm (from 2015 to 2017)
Figure 9 The soil EC changes at depth of 0-100 cm (from 2015 to 2017)
Figure 10 The soil SAR changes at depth of 0-100 cm (from 2015 to 2017)
Figure 11 The soil TA changes at depth of 0-100 cm (from 2015 to 2017)
Irrigation had significant effects on the chemical properties of the soil at different soil depths (0-100 $\mathrm{cm}$, Figure 8-11). For example, the soil EC, SAR, and TA of irrigation treatments showed greater decreasing effects than CK. During the growing season, the average soil EC of different irrigation treatments decreased 
287

288

289

290

291

292

293

294

295

296

297

298

299

300

301

302

303

304

305

306

307

308

309

310

311

312

313

314

315

316

317

318

319

320

210.21-287.24 $\mu \mathrm{S} \mathrm{cm}^{-1}$, and the average soil EC of CK decreased $46.35 \mu \mathrm{S} \mathrm{cm}^{-1}$. The results of soil SAR (average of $0-100 \mathrm{~cm}$ ) revealed that irrigation reduced $8.10-9.00\left(\mathrm{mmol}_{\mathrm{c}} / \mathrm{L}\right)^{1 / 2}$, and on the contrast, the average soil SAR of CK decreased only $0.93\left(\mathrm{mmol}_{\mathrm{c}} / \mathrm{L}\right)^{1 / 2}$ from September 2015 to October 2017.

The greatest decrease of soil TA was observed with the $\mathrm{I} 7$ irrigation treatment $\left(4.64 \mathrm{mmol}_{\mathrm{c}} \mathrm{L}^{-1}\right)$, while the lowest decrease of soil TA was found in the $\mathrm{I} 3$ treatment $\left(3.29 \mathrm{mmol}_{\mathrm{c}} \mathrm{L}^{-1}\right)$, and the soil TA without irrigation decreased $2.88 \mathrm{mmol}_{\mathrm{c}} \mathrm{L}^{-1}$. The effects of irrigation on soil $\mathrm{pH}$ were complicated. For instance, the soil $\mathrm{pH}$ at a depth of $0-40 \mathrm{~cm}$ and $80-100 \mathrm{~cm}$ decreased at $0.003-0.80$, and a $0.13-0.56$ increase of soil $\mathrm{pH}$ at the depth 40-60 $\mathrm{cm}$ was found.

As shown in Figure 8A, I2, I3, I4, and I5 showed a greater decrease on soil $\mathrm{pH}(0-00 \mathrm{~cm}, \Delta \mathrm{pH}=0.14-$ 0.30) than the other treatments. The soil EC of I4 and I5 decreased $283.89 \mu \mathrm{S} \mathrm{cm}^{-1}$ and $287.24 \mu \mathrm{S} \mathrm{cm}^{-1}$, which were larger than other treatments (Figure 9). The soil SAR decreases $8.96\left(\mathrm{mmol}_{\mathrm{c}} / \mathrm{L}\right)^{1 / 2}$ and 9.00 $\left(\mathrm{mmol}_{\mathrm{c}} / \mathrm{L}\right)^{1 / 2}$, which were observed with the I7 and I5 treatments (Figure 10); the soil TA under the treatments of I5, I6, and I7 $\left(\Delta \mathrm{TA}=4.15-4.65 \mathrm{mmol}_{\mathrm{c}} \mathrm{L}^{-1}\right)$ showed a greater decrease than the other treatments (Figure 11).

\section{Discussion}

Alfalfa is a crop with a high water demand (Bauder et al 1992) and its biomass production depends on shoot height, leaf area, and leaf number, which can be reduced drastically by a deficit in the soil water (Saeed \& El-Nadi, 1997). The alfalfa DMs of irrigated treatments in this study ranged from $633.00 \mathrm{~g} \mathrm{~m}^{-2}$ to $1703.00 \mathrm{~g} \mathrm{~m}^{-2}$ and significantly correlated with SH $(\mathrm{r}=0.61, \mathrm{P}<0.01)$, which indicated that water is critical in the biomass production of alfalfa. The high correlation between $\mathrm{SH}$ and biomass production found in this study was in agreement with Davis and Buker (1966) who reported that $65 \%$ of alfalfa yield was determined by shoot height. The WUE of alfalfa in this study was promoted from $1.33 \mathrm{~kg} \mathrm{~m}^{-3}$ to $2.50 \mathrm{~kg} \mathrm{~m}^{-3}$, which agreed with previous reports in cooler, more northerly climates (Stanhill, 1986; Bogler \& Matches, 1990; Grimes et al., 1992; Saeed \& El-Nadi, 1997). The highest WUE was observed in the I5 treatment $(2.50 \mathrm{~kg}$ $\mathrm{m}^{-3}$ ) which was irrigated at the branch stage of alfalfa and then followed by I1 treatment $\left(2.47 \mathrm{~kg} \mathrm{~m}^{-3}\right)$. In addition, results of Kulu et al. (2010) and Estill et al. (1993) indicated that the DM and the WUE of alfalfa were decreased by water shortage. Thus, irrigation is a key factor to maintain and promote the WUE and productivity of artificial grassland (Potters et al., 2007). We also found a significant positive correlation ( $\mathrm{r}$ $=0.42, \mathrm{P}<0.05)$ between WUE and the amount of irrigation water in this study. Water shortage significantly hindered the plant cell elongation, reduced photosynthesis, interfered with water and nutrient uptake, and changed the plant hormone levels (Saeed \& El-Nadi 1997; Antolín and Sánchez-Díaz, 1993). Thus, the results of this study indicated that the branch stage is the most important period for alfalfa in determining the stem density, shoot height, and the area and amount alfalfa leaf. Moreover, the SLR results showed that the effect of irrigation on SLR was not significant $(P>0.05)$, however, the SLR of CK 
321 treatment was decreased compared to I1, I4, and I5, which indicated that the forage quality might increase

322 under irrigation. Furthermore, results of this study showed that there is a difference between precipitation

323 and evaporation in the western Songnen Plain. Therefore, in order to promote the WUE, DM and quality

324 of crops in this region, perennial crops such as alfalfa should be irrigated in a rational schedule.

325 Plants, through their capacity to assimilate, transport, and evaporate soil water, leave a strong imprint 326 on water and salt dynamics. In addition, the dynamics of soluble salts in soils are significantly linked to 327 water movement through the ecosystem-vadose zone-aquifer continuum (Nosetto et al., 2007). While most 328 of the knowledge about the effects of irrigation and vegetation on salt dynamics derive from higher 329 evapotranspiration rates that drive the movement of groundwater and salt, and increased soil macro-porosity 330 enhancing water infiltration and salt flushing. Results of this study indicated that the I2, I5, and I7 treatments 331 showed better effects of de-salinization and de-alkalization than the other irrigation treatments. For 332 instance, the 0.23 and 0.29 of soil $\mathrm{pH}$ of I2 and I5 treatments were decreased by irrigation, which was 333 similar to the research of Dong et al. (2001). Research of Cao et al. (2012) indicated that the soil EC and 334 concentration of $\mathrm{HCO}_{3}{ }^{-}$decreased after planting alfalfa for 3 years in the Yingda irrigation district. Many 335 field experiments indicated that the vegetation decreased evaporation and salt accumulation in the surface 336 soil (Ghaly, 2002; Lin et al., 2003). Our research also noted that the soil EC of I2, I5, and I7 declined 240.30 $337 \mu \mathrm{S} \mathrm{cm}^{-1}, 287.25 \mu \mathrm{S} \mathrm{cm} \mathrm{cm}^{-1}$, and $253.10 \mu \mathrm{S} \mathrm{cm}^{-1}$; additionally, the soil TA of I2, I5, and I7 diminished 3.98 $338 \mathrm{mmol}_{\mathrm{c}} \mathrm{L}^{-1}, 4.15 \mathrm{mmol}_{\mathrm{c}} \mathrm{L}^{-1}$ and $4.65 \mathrm{mmol}_{\mathrm{c}} \mathrm{L}^{-1}$, respectively. These results may be attributed to the deep 339 taproot system of alfalfa (Raiesi, 2007; Yong, 2007). Evapotranspiration decreased with vegetation cover 340 (Nosetto et al., 2007). Furthermore, large amounts of salts in the soil were absorbed and moved out of the 341 root zone by the harvested forages, however, there were less salts from irrigation and precipitation in the 342 soils. These factors may contribute to the chemical property changes in the soil of the western Songnen 343 Plain, Northeast China.

\section{Conclusions}

345 Results of this study demonstrated that the DM and WUE of alfalfa in saline-alkali artificial grasslands 346 were promoted from $114.00 \mathrm{~g} \mathrm{~m}^{-2}$ to $1703.00 \mathrm{~g} \mathrm{~m}^{-2}$ and $1.33 \mathrm{~kg} \mathrm{~m}^{-3}$ to $2.50 \mathrm{~kg} \mathrm{~m}^{-3}$ by irrigation, respectively. 347 In addition, the soil EC, SAR, and TA (depth of 0-100 cm) were decreased by irrigation. Considering the 348 local precipitation, evaporation, water resources, and backgrounds of soil chemical properties, $236.50 \mathrm{~mm}$ 349 of irrigation water at the branch stage was recommended for artificial grassland in the western Songnen 350 Plain, Northeast China.

\section{Acknowledgements}

\section{References}

353 Bin Li, Zhichun Wang, Chunming Chi. 2006. Parameters and characteristics of alkalization of sodic soil in Da'an 354 City. Journal of Ecology and Rural Environment 22:20-23 (in Chinese with English abstract). 
355

356

357

358

359

360

361

362

363

364

365

366

367

368

369

370

371

372

373

374

375

376

377

378

379

380

381

382

383

384

385

386

387

388

389

390

391

392

393

Chunming Chi, Zhichun Wang. 2010. Characterizing salt-affected soils of Songnen Plain using saturated paste and 1:5 soil-to-water extraction methods. Arid Land Research Management 24(1), 1-11. DOI: $10.1080 / 15324980903439362$

CY Wang, ZJ Wu, YL Shi, RY Wang. 2004. The resource of saline soil in the Northeast China. Chinese Journal of Soil Science 35(5):643-647 (In Chinese with English abstract).

DC Shi, DL Wang. 2005. Effects of various salt-alkaline mixed stresses on Aneurolepidium chinense (Trin.) Kitag. Plant and Soil 271(1-2):15-26. DOI: 10.1007/s11104-004-1307-z

Donald W Grimes, Paul L Wiley, WR Sheesley. 1992. Alfalfa yield and plant water relations with variable irrigation. Crop Science 32:1381-1387. DOI: 10.2135/cropsci1992.0011183X003200060015x

Ebru Bandeoğlu, Füsun Eyidoğan, Meral Yücel, Hüseyin Avni Öktem. 2004. Antioxidant responses of shoots and roots of lentil to NaCl-salinity stress. Plant Growth Regulation 42(1):69-77. DOI: 10.1023/B:GROW.0000014891.35427.7b

FAO. 2002. Deficit irrigation practices. FAO Water Report No. 22, Rome.

Fatma M Ghaly. 2002. Role of natural vegetation in improving salt affected soil in northern Egypt. Soil \& Tillage Research 64(3-4):173-178. DOI: 10.1016/S0167-1987(01)00240-9

Fayez Raiesi. 2007. The conversion of overgrazed pastures to almond orchards and alfalfa cropping systems may favor microbial indicators of soil quality in Central Iran. Agriculture Ecosystems \& Environment 121:309-318. DOI: 10.1016/j.agee.2006.11.002

Frank Van Breusegem, Eva Vranová, James F Dat, Dirk Inzé. 2001. The role of active oxygen species in plant signal transduction. Plant Science 161:405-414. DOI: 10.1016/S0168-9452(01)00452-6

G Stanhill. 1986. Water use efficiency. Advances in Agronomy 39:53-85. DOI: 10.1016/S0065-2113(08)60465-4

Geert Potters, Taras P Pasternak, Yves Guisez, Klaus J Palme. 2007. Stress-induced morphogenic responses: growing out of trouble. Trends in Plant Science 12(3):98-105. DOI: 10.1016/j.tplants.2007.01.004

HM Lin, HX Jia, YF Zhang. 2003. Effect of salt restraint on Vicia villosa in secondary salinization land. Acta Prataculturae Sinica 12(4): 58-62.

IAM Saeed, AH El-Nadi. 1997. Irrigation effects on the growth, yield, and water use efficiency of alfalfa. Irrigation Science 17:63-68. DOI: 10.1007/s00271005002

Jing Cao, Xianting Li, Xiaole Kong, Zed Rengel, Liping Dong. 2012. Using alfalfa (Medicago sativa L.) to ameliorate salt-affected soils in Yingda irrigation district in Northwest China. Acta Ecologica Sinica 32(2):68-73. DOI: 10.1016/j.chnaes.2011.12.001

JJ Ojedaa, OP Caviglia, MG Agnusdei, PM Errecart. 2018. Forage yield, water- and solar radiation-productivities of perennial pastures and annual crops sequences in the south-eastern Pampas of Argentina. Field Crops Research 221:19-31. DOI: 10.1016/j.fcr.2018.02.010

JW Bauder, JS Jacobsen, WT Lanier. 1992. Alfalfa emergence and survival response to irrigation water quality and soil series. Soil Science Society of America Journal 56:890-896. DOI: 10.2136/sssaj1992.03615995005600030035x

K Estill, RH Delaney, RL Ditterline, WK Smith. 1993. Water relations and productivity of alfalfa populations divergently selected for leaflet size. Field Crops Research 33:423-434. DOI: 10.1016/0378-4290(93)90163-h

KK Tanji. 1990. Nature and extent of agricultural salinity. In: Agricultural salinity assessment and management. (ed. K.K. Tanji), pp. 1-17. American Society of Civil Engineers, New York, NY.

PeerJ reviewing PDF | (2018:12:33526:1:2:NEW 28 Apr 2019) 
394

395

396

397

398

399

400

401

402

403

404

405

406

407

408

409

410

411

412

413

414

415

416

417

418

419

420

421

422

423

424

425

426

427

428

429

430

431

M Koca, M Bor, F Ozdemir, I Turkan. 2007. The effect of salt stress on lipid peroxidation, antioxidative enzymes and proline content of sesame cultivars. Environmental and Experimental Botany 60:344-351. DOI: 10.1016/j.envexpbot.2006.12.005

Manzoor Qadir, Andrew D Noble, JD Oster, Sven Schubert, Abdul Ghafoor. 2005. Driving forces for sodium removal during phytoremediation of calcareous sodic and saline-sodic soils: a review. Soil Use and Management 21:173-180. DOI: 10.1111/j.1475-2743.2005.tb00122.x

Manzoor Qadir, Ashraf Tubeileh, Javaid Akhtar, Asamoah Larbi, PS Minhas, M Ajmal Khan. 2008. Productivity enhancement of salt-affected environments through crop diversification. Land Degradation \& Development 19:429-453. DOI: 10.1002/ldr.853

Manzoor Qadir, S Schubert. 2002. Degradation processes and nutrient constraints in sodic soils. Land Degradation and Development 13:275-294. DOI: 10.1002/ldr.504

Manzoor Qadir, Sven Schubert, Abdul Ghafoor, Ghulam Murtaza. 2001. Amelioration strategies for sodic soils: a review. Land Degradation \& Development 12:357-386. DOI: 10.1002/ldr.458

Marcelo D Nosetto, Jobbágy G Esteban, Tibor Tóth, Carlos M. Di Bella. 2007. The effects of tree establishment on water and salt dynamics in naturally salt-affected grasslands. Oecologia 152:695-705. DOI: 10.1007/s00442007-0694-2

MC Antolín, M Sánchez-Díaz. 1993 Effects of temporary droughts on photosynthesis of alfalfa plants. Journal of Experimental Botany, 44:1341-1349. DOI: 10.1093/jxb/44.8.1341

ME Jensen. 1968. Water comsumption by agricultural plants. TT Kozlowski (Ed.), Water Deficits in Plant Growth, 1, pp. 1-22. Academic Press, New York, USA.

Mingming Wang, Pichu Rengasamy, Zhichun Wang, Fan Yang, Hongyuan Ma, Lihua Huang, Miao Liu, Haoyu Yang, Jingppeng Li, Fenghua An, Yangyang Li, Xiaolong Liu, Zhengwei Liang. 2018. Identification of the most limiting factor for rice yield using soil data collected before planting and during the reproductive stage. Land Degradation and Development 29(8):23102320 DOI: 10.1002/ldr.3026

Niculae Dincă, Daniel Dunea, Stefano Casadei, Nicolae Petrescu, Sebastian Barbu. 2017. An assessment of the water use efficiency in alfalfa cnopy under the climate regime of trgoviste piedmont plain. Agronomy, LX:235-240.

PR Carter, CC Sheaffer. 1983. Alfalfa response to soil water deficit. I. Growth, forage quality, yield, water use, and water-use efficiency. Crop Sci. 23:669-675. DOI: 10.2135/cropsci1983.0011183X002300040016x

Rajbir Singh, Dilip Kumar Kundu, KK Bandyopadhyay. 2010. Enhancing Agricultural Productivity through Enhanced Water Use Efficiency. Journal of Agricultural Physics 10:1-15.

Richard G Allen, Luis S Pereira, Dirk Raes, Martin Smith. 1998. Crop Evapotranspiration: guidelines for Computing Crop Water Requirements. Food and Agriculture Organization of the United Nations, Rome.

RL Davis, RJ Buker. 1966. Predicting yields from associated characters in Medieago sativa L. Crop Science 2:492494. DOI: $10.2135 /$ cropsci1966.0011183X000600050032x

Ted Van der Gulik T. 2001. Crop coefficients for use in irrigation scheduling. Ministry of Agriculture, Food and Fisheries of British Columbia. Agdex 561. http://irrigationtoolbox.com/ReferenceDocuments/Extension/BCExtension/577100-5.pdf

TP Bogler, AG Matches. 1990. Water use efficiency and yield of sainfoin and alfalfa. Crop Science 30:143-148. DOI: 10.2135/cropsci1990.0011183X003000010032x 
432 U Sahin, A Hanay. 1996. Irrigation scheduling for the planned crop-pattern to be grown in Daphan plain of Erzurum by means of computer techniques. Turkish Journal of Agriculture and Forestry 20:415-423.

United States Department of Agriculture (USDA). 1954. Diagnosis and Improvement of Saline and Alkali Soils. Agriculture Handbook No. 60. United States Salinity Laboratory, Riverside, CA.

Xiaoxia Dong, Hongmei Guo, Ling'an Kong. 2001. Effects of alfalfa cultivation in costal saline soil region on soil fertilizer and salts. Shandong agriculture sciences 1(12):24-25. (In Chinese)

Y Kuslu, U Sahin, T Tunc, FM Kiziloglu. 2010. Determining water-yield relationship, water use efficiency, seasonal crop and pan coefficients for alfalfa in a semiarid region with high altitude. Bulgarian Journal of Agricultural Science 16 (4):482-492.

Zhenggang Guo, Huixia Liu, Suomin Wang, Fuping Tian, Guodong Cheng. 2005. Biomass, persistence, and drought resistance of nine lucerne varieties in the dry land environment of West China. Australian Journal of Experimental Agriculture 45:59-64. DOI: $10.1071 / \mathrm{EA} 03119$

Zhenggang Guo, Huixia Liu, Yanrong Wang, Kunhu Yu, Jingning Yang. 2007. Irrigating at podding and regrowth stages increases seed yield and improves pod distribution in lucerne grown in the Hexi Corridor in China. New Zealand Journal of Agricultural Research 50:285-290. DOI: 10.1080/00288230709510296

Zhongsu Yong. 2007. Soil carbon and nitrogen sequestration following the conversion of cropland to alfalfa forage land in northwest China. Soil \& Tillage Research 92:181-189. DOI: 10.1016/j.still.2006.03.001 
Figure $\mathbf{1}$ (on next page)

The monthly precipitation and evaporation of the study site (recorded from 2008.1.1 to 2018.7.31)

This figure showed the monthly precipititation and evaporation of the study site from 2008.1.1 to 2018.7.31 


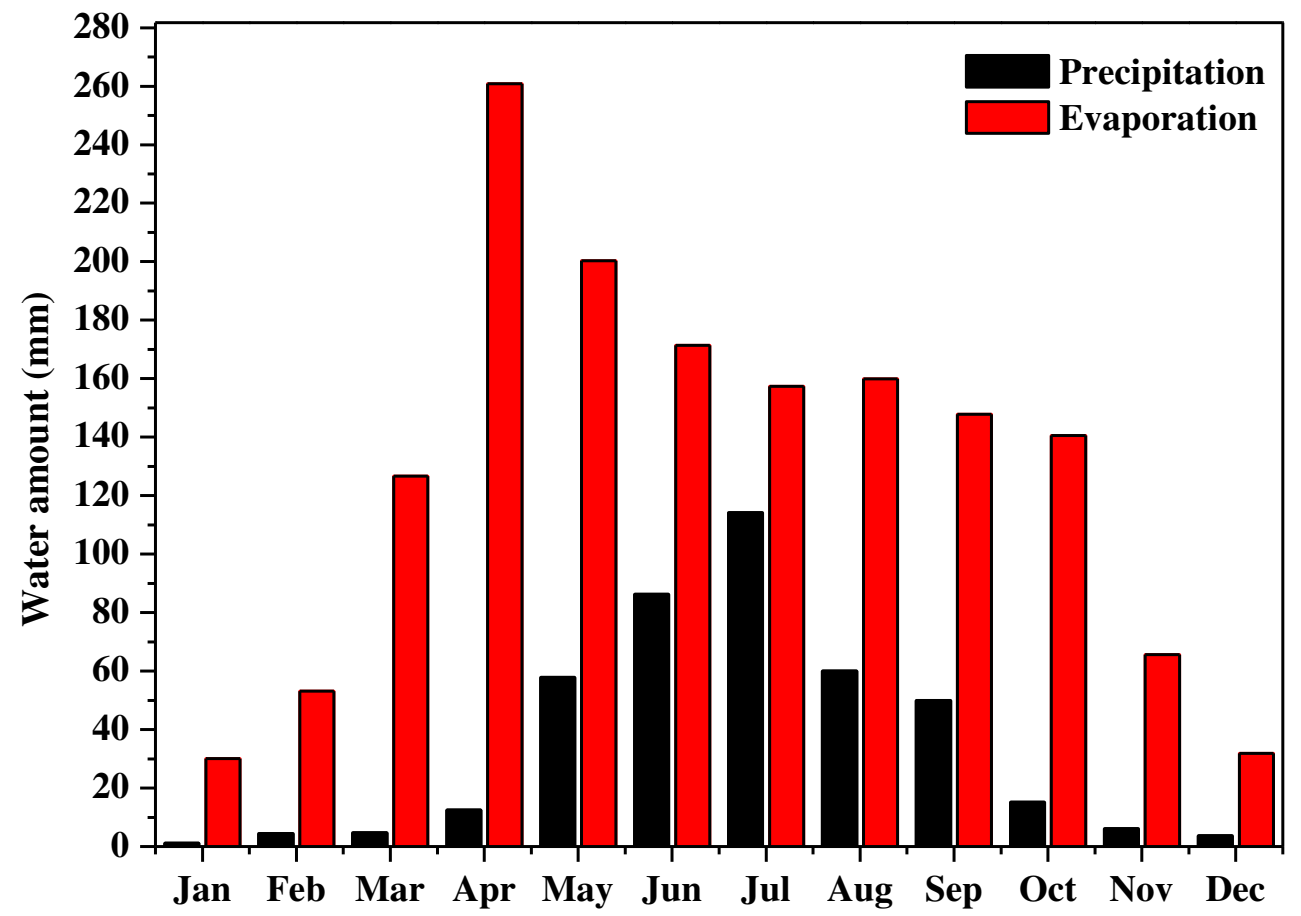




\section{Figure 2}

The distribution and area of experiment plots

The Figure 2 showed us that the distribution and area of the irrigation plots in this study, in addition, the total numbers of irrigation plots were also displayed.

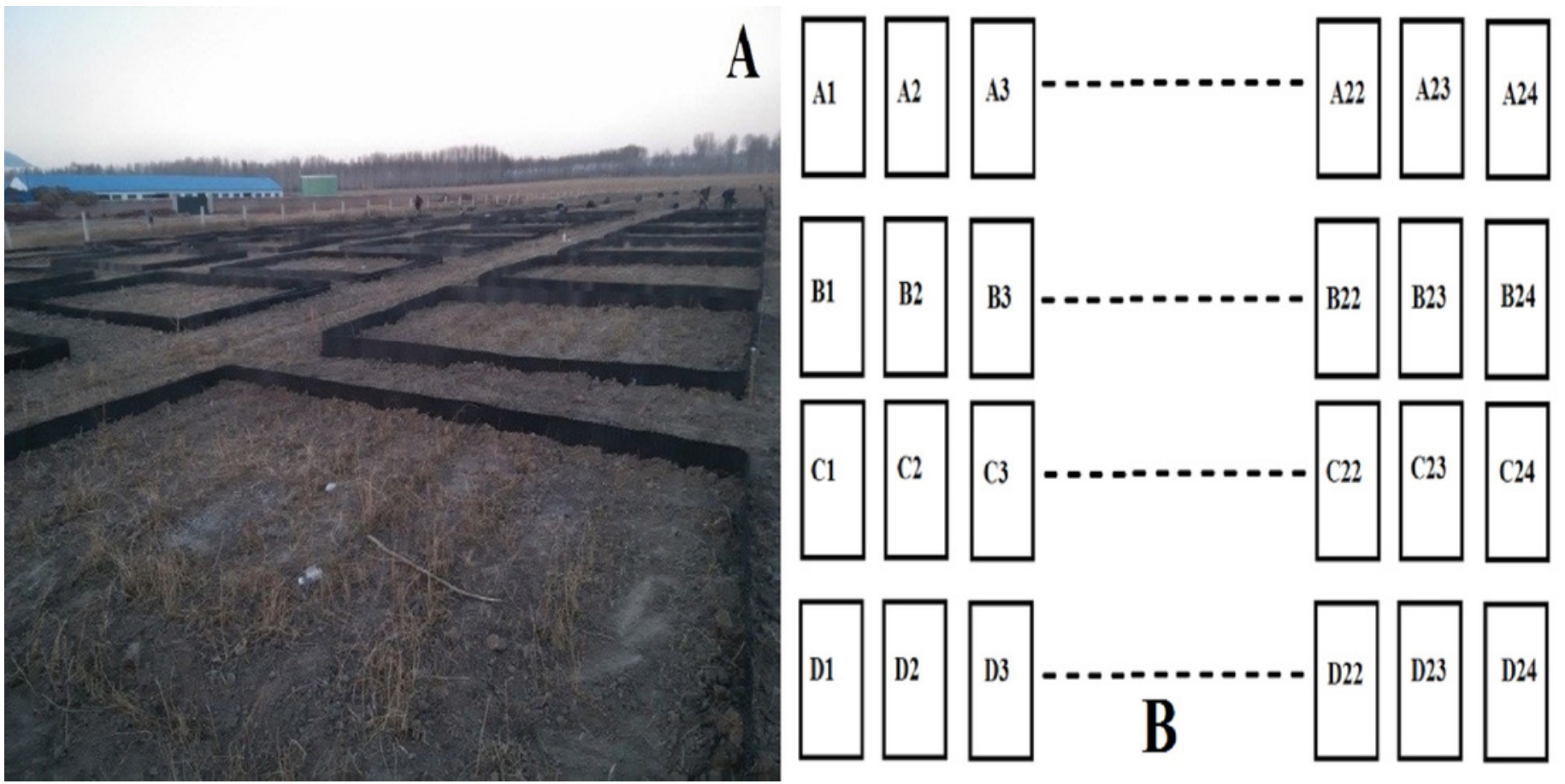


Figure 3 (on next page)

The monthly precipitation and evaporation during the growing season of alfalfa ( $P$, precipitation, $\mathrm{mm}$; E, evaporation, $\mathrm{mm}$ )

The Figure 3 displayed the monthly precipitation and evaporation during the alfalfa growing season (from April to October) 


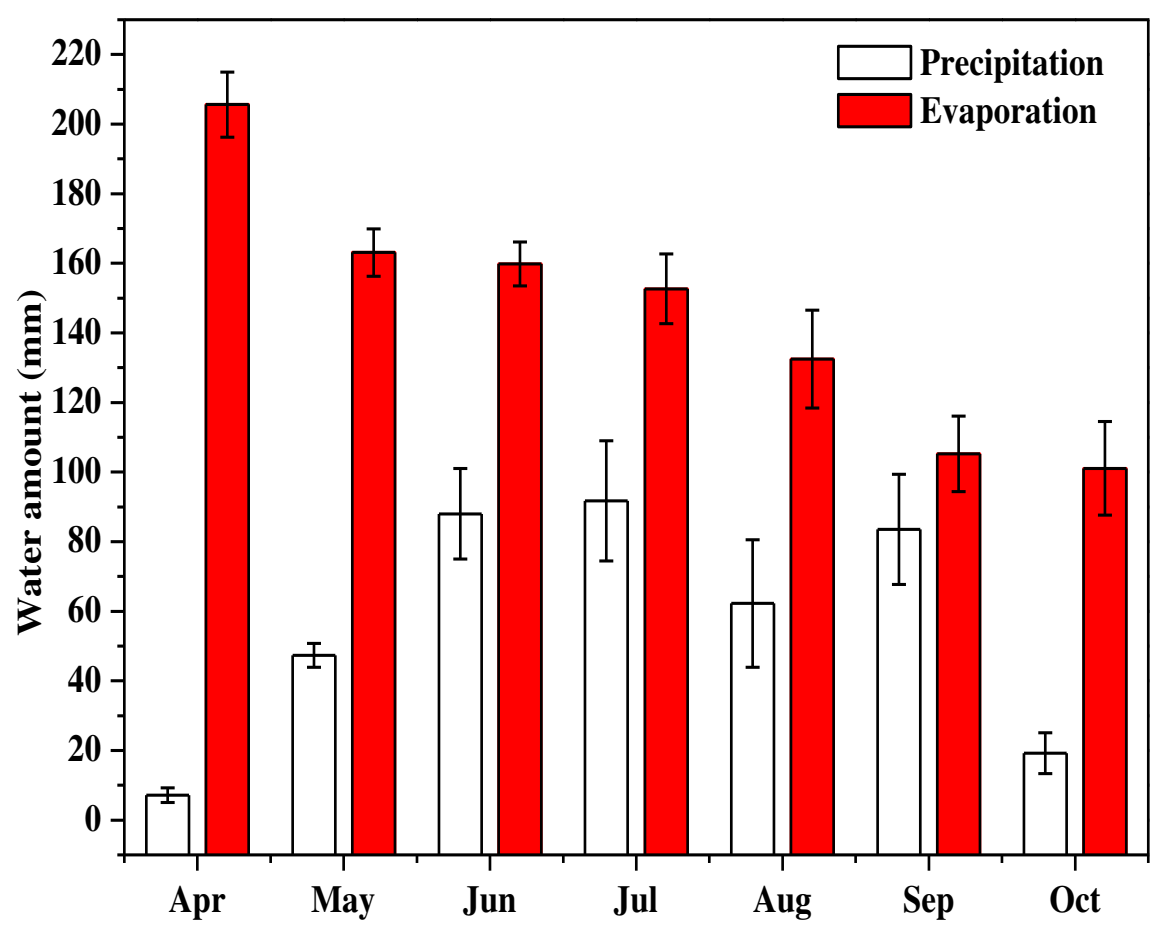


Figure 4 (on next page)

The WUE and water consumption of different treatments $(P<0.05)$

The Figure 4 displayed the water use efficiency and the total water consumption of the eight irrigation treatments in this study 

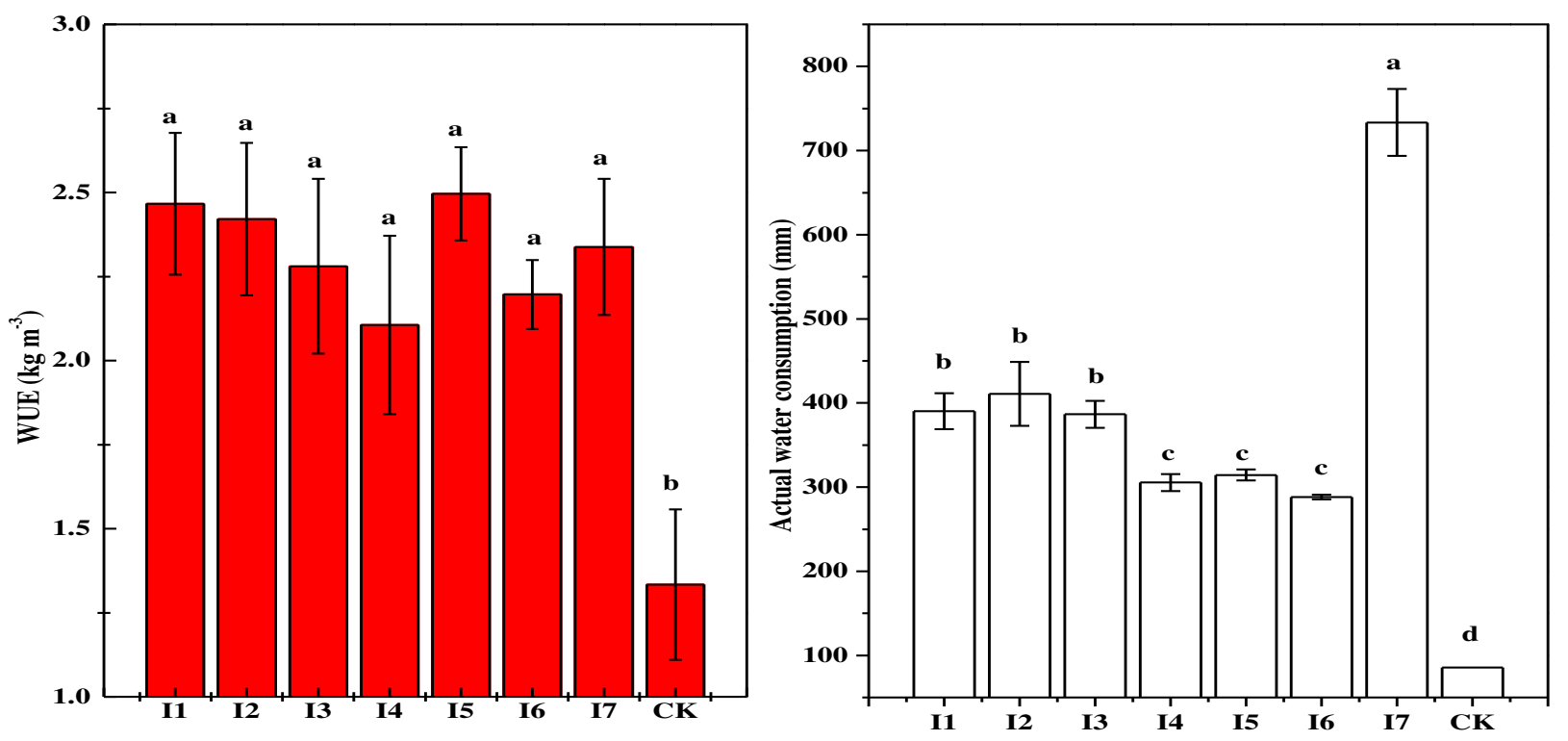
Figure $\mathbf{5}$ (on next page)

The water sensitive index of alfalfa ( $R$, regreen period; $B$, branch period; $A$, flower period)

The Figure 4 showed us that the water sensitive index of alflafa in regreen, branch, and flower stage 


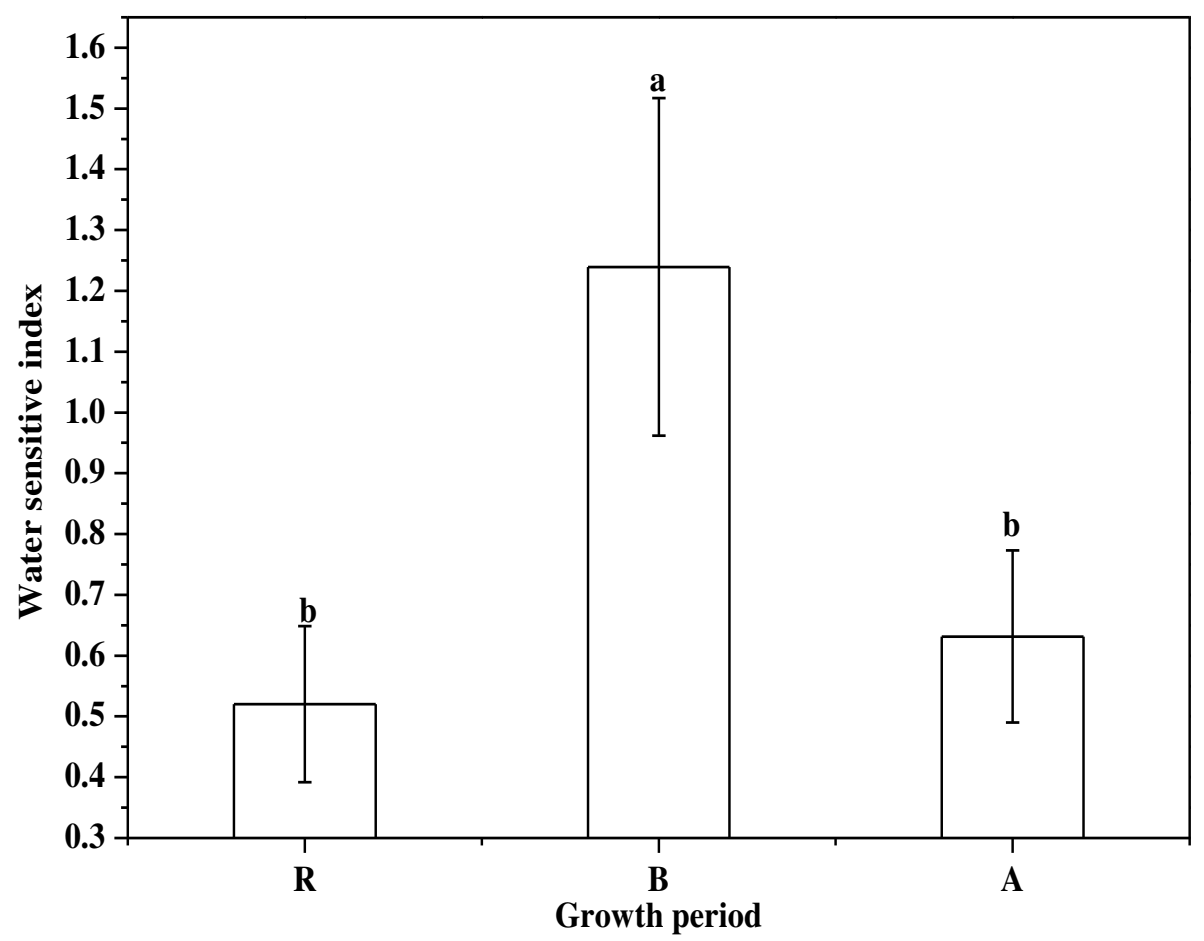


Figure 6

Actual and simulated of alfalfa yield and the relations to the irrigation amount (DM-J, alfalfa yield simulated by Jensen Model, $t \mathrm{th}^{-1}$; DM-A, actual alfalfa yield, $\mathrm{t} \mathrm{ha}{ }^{-1}$ )

The actual alfalfa yield and simulated yield by Jensen Model were correlated to the amount of irrigation, respectively, and the results were shown in the Figure 6.

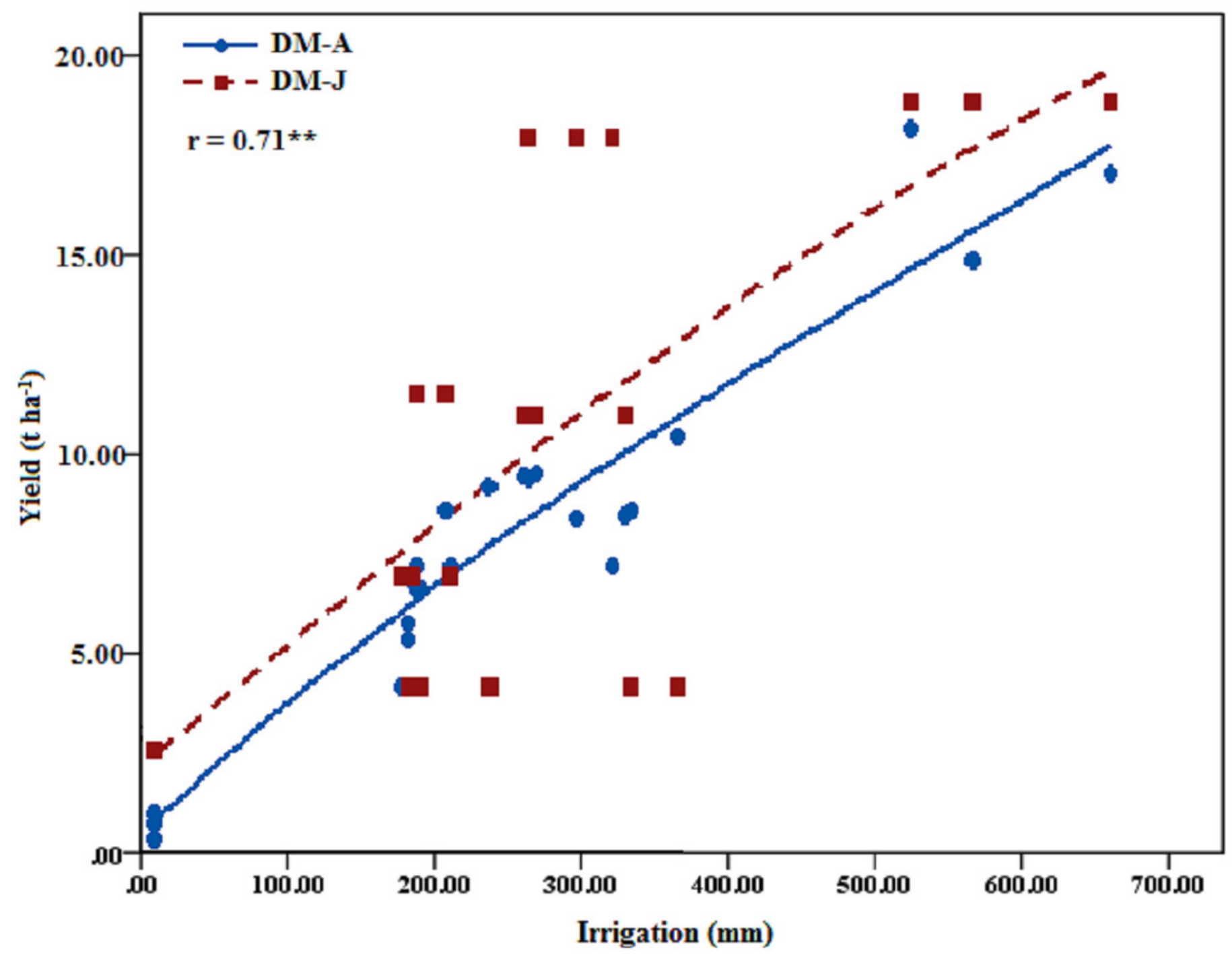


Figure 7

The relation between amount of irrigation and actual alfalfa yield

We have calculated the relation between the actual alfalfa yield and the amount of irrigation by curve fitting program in SPSS 20.0 in this study and the result was shown in the Figure 7.

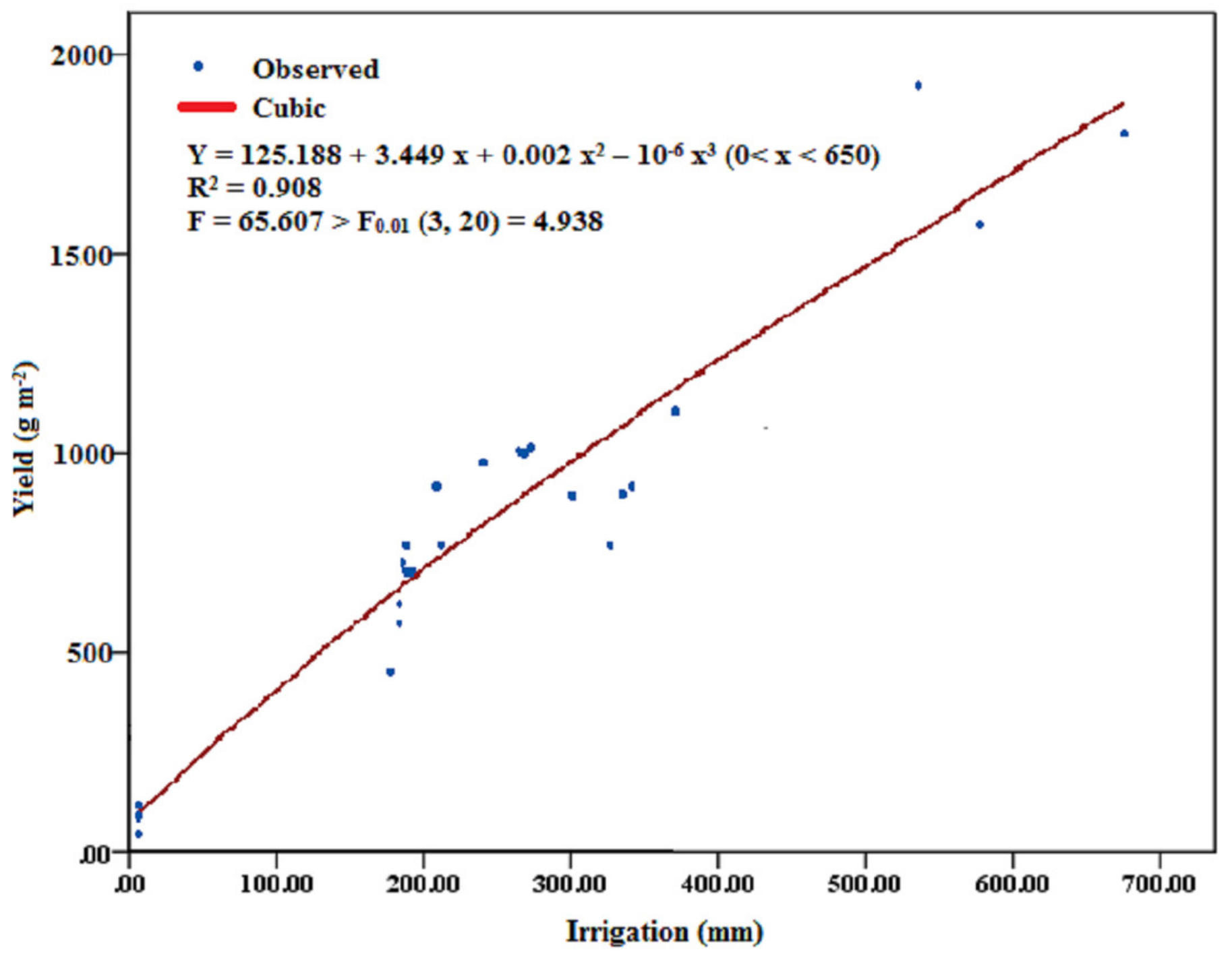


Figure 8

The soil pH changes of different irrigation treatments at depth of 0-100 cm (from 2015 to 2017)

The changes of soil pH from 2015 to 2017 were shown in the Figure 8.
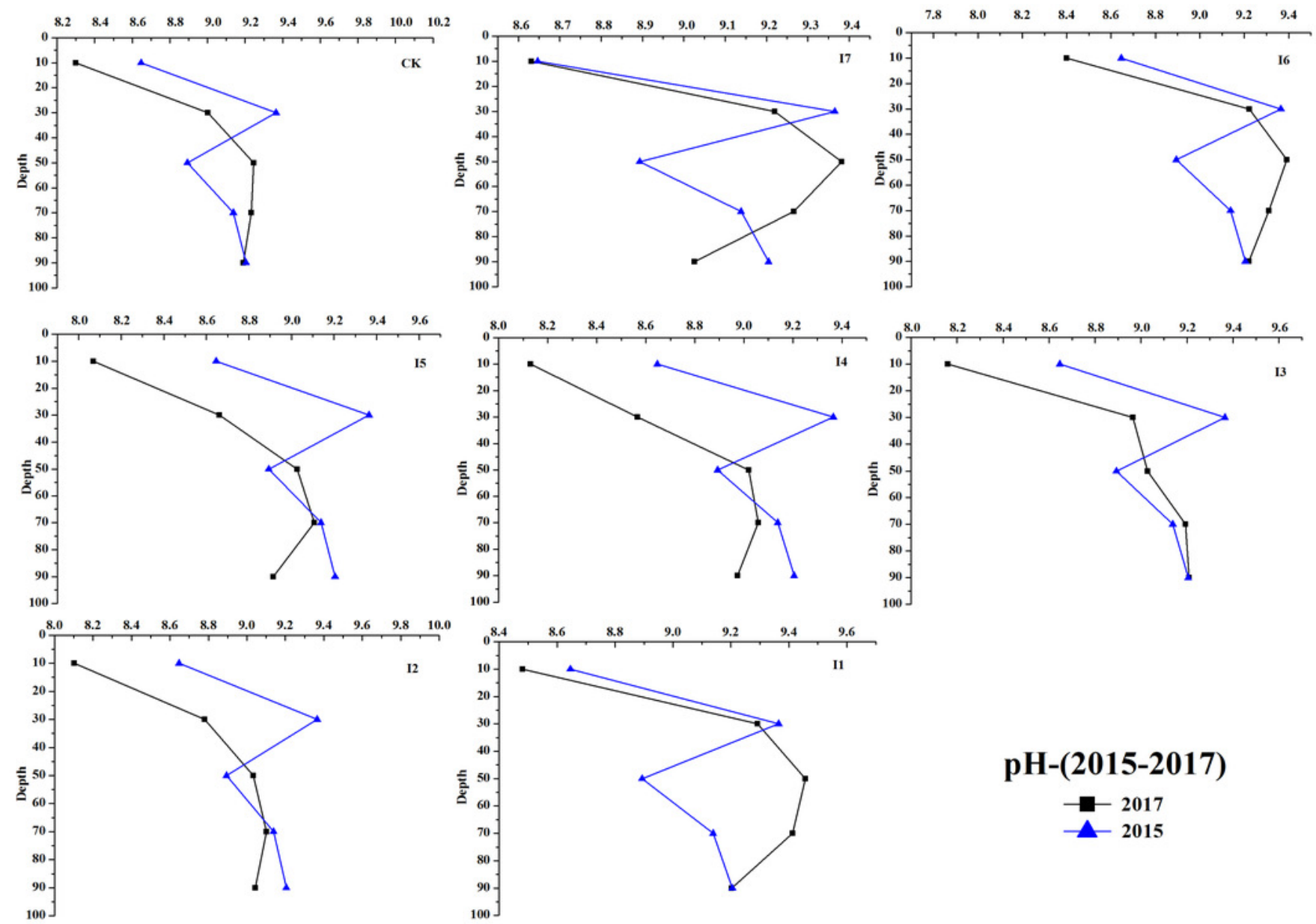

pH-(2015-2017) 
Figure 9

The soil EC changes of different irrigation treatments at depth of 0-100 cm (from 2015 to 2017)

This Figure showed us that the soil EC changes at depth of 0-100 cm from 2015 to 2017
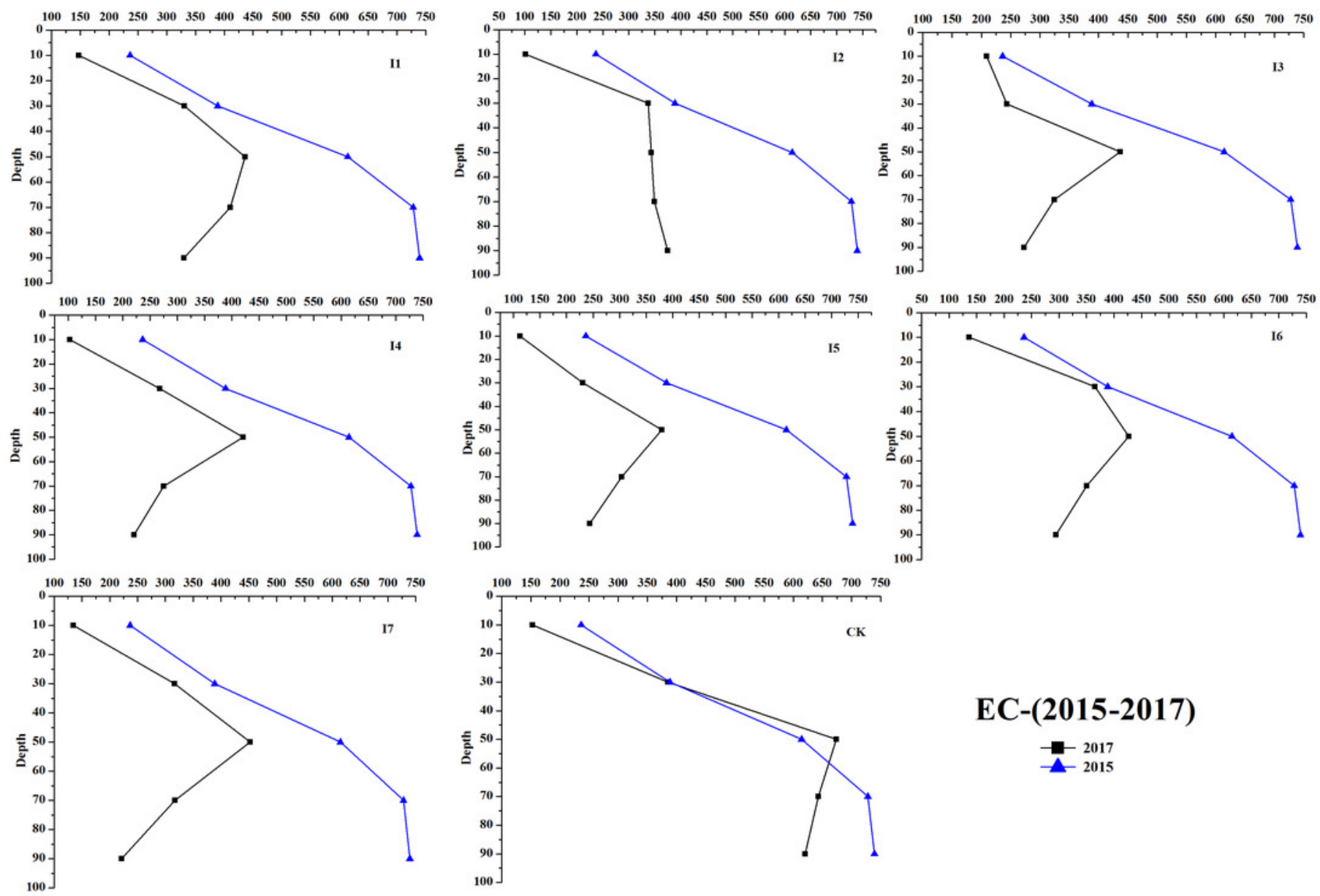

EC-(2015-2017)

2017
-2015 
Figure 10

The soil SAR changes of different irrigation treatments at depth of 0-100 cm (from 2015 to 2017)

The Figure 8C displayed the soil SAR changes from 2015 to 2017 at depth of $0-100 \mathrm{~cm}$
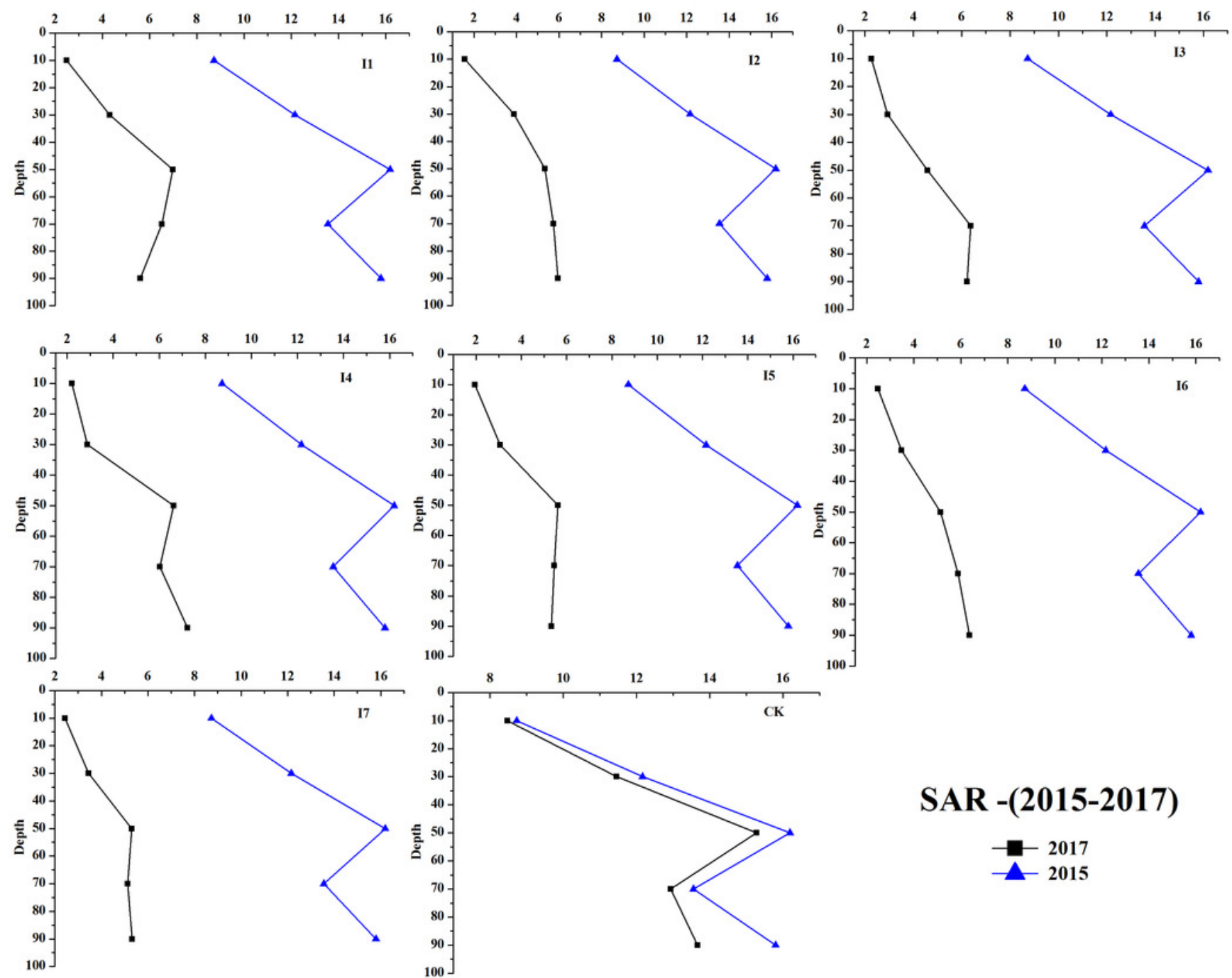

SAR -(2015-2017)

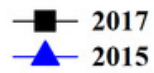


Figure 11

The soil TA changes of different treatments at depth of 0-100 cm (from 2015 to 2017)

The result of soil TA changes at depth of 0-100 cm was shown in Figure 8D
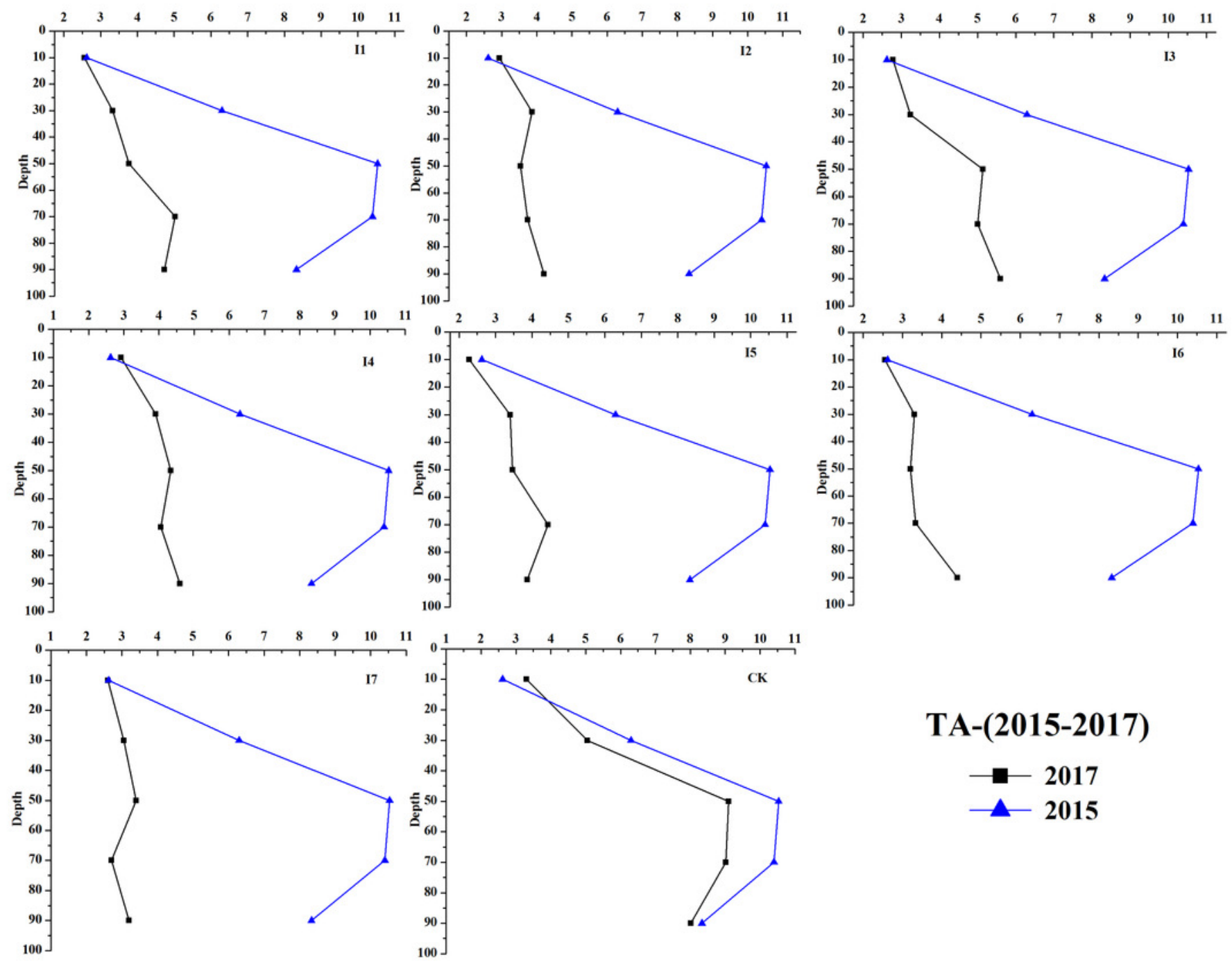

TA-(2015-2017)

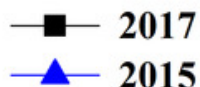




\section{Table $\mathbf{1}$ (on next page)}

The backgrounds of soil physico-chemical properties

Note, EC, electrical conductivity; SAR, sodium absorption ratio; TA, total alkalinity 
1

2

Table 1 The backgrounds of soil physico-chemical properties

\begin{tabular}{|c|c|c|c|c|}
\hline Depth & Parameter & Average & Maximum & Minimum \\
\hline \multirow{7}{*}{$\begin{array}{l}\tilde{0} \\
8 \\
8 \\
\text { ? } \\
\text { ? }\end{array}$} & $\mathrm{pH}$ & $9.33 \pm 0.09$ & 10.45 & 8.52 \\
\hline & $\mathrm{EC}\left(\mu \mathrm{S} \mathrm{cm} \mathrm{cm}^{-1}\right)$ & $330.18 \pm 33.18$ & 886.00 & 69.60 \\
\hline & $\operatorname{SAR}\left(\left(\mathrm{mmol}_{\mathrm{c}} / \mathrm{L}\right)^{1 / 2}\right)$ & $7.65 \pm 1.65$ & 27.41 & 0.27 \\
\hline & TA $\left(\mathrm{mmol}_{\mathrm{c}} \mathrm{L}^{-1}\right)$ & $4.35 \pm 0.73$ & 13.60 & 1.40 \\
\hline & Bulk density $\left(\mathrm{g} \mathrm{cm}^{-3}\right)$ & $1.59 \pm 0.01$ & 1.75 & 1.40 \\
\hline & Field capacity (\%) & $37.07 \pm 0.44$ & 37.07 & 23.48 \\
\hline & Porosity (\%) & $40.12 \pm 0.36$ & 47.29 & 33.81 \\
\hline & Sand $(\%,>0.02 \mathrm{~mm})$ & \multicolumn{3}{|c|}{84.44} \\
\hline $\begin{array}{l}\text { हี } \\
\stackrel{\text { ते }}{2}\end{array}$ & Silt $(\%, 0.002 \sim 0.02)$ & \multicolumn{3}{|c|}{10.68} \\
\hline ? & Clay $(\%,<0.002 \mathrm{~mm})$ & \multicolumn{3}{|c|}{4.87} \\
\hline & Sand $(\%,>0.02 \mathrm{~mm})$ & \multicolumn{3}{|c|}{44.13} \\
\hline : & Silt $(\%, 0.002 \sim 0.02)$ & \multicolumn{3}{|c|}{44.12} \\
\hline$\stackrel{2}{2}$ & Clay $(\%,<0.002 \mathrm{~mm})$ & \multicolumn{3}{|c|}{11.75} \\
\hline
\end{tabular}

Note, EC, electrical conductivity; SAR, sodium absorption ratio; TA, total alkalinity 


\section{Table 2 (on next page)}

The experiment design

Note, C, designed irrigation coefficient; R, regreen stage, B, branch sage, F, flower stage;

$\mathrm{ET}_{1}$, the mean reference $\mathrm{ET}$ for alfalfa regreen stage, $\mathrm{mm} ; \mathrm{ET}_{2}$, the mean reference $\mathrm{ET}$ for alfalfa branch stage, $\mathrm{mm} ; \mathrm{ET}_{3}$, the mean reference $\mathrm{ET}$ for alfalfa flower stage, $\mathrm{mm}$; 
1

Table 2 The experiment design

\begin{tabular}{|c|c|c|c|c|c|c|c|c|}
\hline Treatments & $\mathrm{C}$ & $\begin{array}{c}\text { Irrigation amount } \\
(\mathrm{mm})\end{array}$ & $\begin{array}{c}\text { Irrigation } \\
\text { time }\end{array}$ & $\begin{array}{l}\text { Irrigation } \\
\text { mode }\end{array}$ & Replications & $\mathrm{ET}_{1}$ & $\mathrm{ET}_{2}$ & $\mathrm{ET}_{3}$ \\
\hline I1 & $60 \%$ & $236.50 \times 2=473.00$ & $R+B$ & \multirow{7}{*}{ 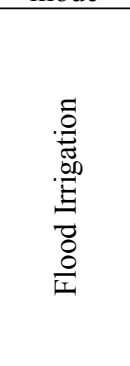 } & 12 & 1176.12 & 1248.76 & 424.15 \\
\hline $\mathrm{I} 2$ & $60 \%$ & $236.50 \times 2=473.00$ & $\mathrm{~B}+\mathrm{F}$ & & 12 & 1176.12 & 1248.76 & 424.15 \\
\hline $\mathrm{I} 3$ & $60 \%$ & $236.50 \times 2=473.00$ & $\mathrm{R}+\mathrm{F}$ & & 12 & 1176.12 & 1248.76 & 424.15 \\
\hline I4 & $30 \%$ & $236.50 \times 1=236.50$ & $\mathrm{R}$ & & 12 & 1176.12 & 1248.76 & 424.15 \\
\hline I5 & $30 \%$ & $236.50 \times 1=236.50$ & B & & 12 & 1176.12 & 1248.76 & 424.15 \\
\hline I6 & $30 \%$ & $236.50 \times 1=236.50$ & F & & 12 & 1176.12 & 1248.76 & 424.15 \\
\hline I7 & $90 \%$ & $236.50 \times 3=709.50$ & $\mathrm{R}+\mathrm{B}+\mathrm{F}$ & & 12 & 1176.12 & 1248.76 & 424.15 \\
\hline CK & $0 \%$ & 0 & - & Rain-fed & 12 & 1176.12 & 1248.76 & 424.15 \\
\hline & - & - & - & - & 96 & - & - & - \\
\hline
\end{tabular}

2 Note, $\mathrm{C}$, designed irrigation coefficient; $\mathrm{R}$, regreen stage, $\mathrm{B}$, branch sage, F, flower stage; $\mathrm{ET}_{1}$, the mean reference ET

3 for alfalfa regreen stage, $\mathrm{mm} ; \mathrm{ET}_{2}$, the mean reference $\mathrm{ET}$ for alfalfa branch stage, $\mathrm{mm} ; \mathrm{ET}_{3}$, the mean reference $\mathrm{ET}$

4 for alfalfa flower stage, $\mathrm{mm}$; 
Table 3 (on next page)

The DM, SH, SPAD, and SLR of alfalfa under different treatments 
Table 3 The DM, SH, SPAD, and SLR of alfalfa under different treatments

\begin{tabular}{ccccccccc}
\hline & I1 & I2 & I3 & I4 & I5 & I6 & I7 & CK \\
\hline SLR & $2.06 \pm 0.09 \mathrm{a}$ & $2.24 \pm 0.08 \mathrm{a}$ & $2.17 \pm 0.06 \mathrm{a}$ & $2.08 \pm 0.07 \mathrm{a}$ & $1.87 \pm 0.03 \mathrm{a}$ & $2.24 \pm 0.06 \mathrm{a}$ & $2.62 \pm 0.07 \mathrm{a}$ & $2.14 \pm 0.01 \mathrm{a}$ \\
$\mathrm{DM}$ & $953 \pm 34.20 \mathrm{~b}$ & $980 \pm 52.92 \mathrm{~b}$ & $873 \pm 34.64 \mathrm{~b}$ & $647 \pm 94.04 \mathrm{c}$ & $787 \pm 59.25 \mathrm{c}$ & $633 \pm 35.28 \mathrm{c}$ & $1703 \pm 97.01 \mathrm{a}$ & $114 \pm 19.16 \mathrm{~d}$ \\
SH & $109.78 \pm 3.61 \mathrm{bc}$ & $110.22 \pm 1.79 \mathrm{bc}$ & $110 \pm 4.67 \mathrm{bc}$ & $98.67 \pm 5.35 \mathrm{~b}$ & $115.44 \pm 1.93 \mathrm{ab}$ & $104 \pm 3.86 \mathrm{~b}$ & $123.78 \pm 2.41 \mathrm{a}$ & $55.11 \pm 1.44 \mathrm{e}$ \\
SPAD & $58.21 \pm 3.04 \mathrm{a}$ & $58.89 \pm 1.49 \mathrm{a}$ & $60.21 \pm 3.60 \mathrm{a}$ & $64.28 \pm 2.20 \mathrm{a}$ & $59.71 \pm 4.64 \mathrm{a}$ & $61.30 \pm 3.04 \mathrm{a}$ & $64.87 \pm 0.98 \mathrm{a}$ & $53.33 \pm 5.71 \mathrm{a}$
\end{tabular}

2 Note, SLR, mass ratio of stems to leaves; DM, dry yield, $\mathrm{g} \mathrm{m}{ }^{-2} ; \mathrm{SH}$, shoot height of alfalfa, $\mathrm{cm}$; II, irrigate at regreen and branch stages; I2, irrigate at branch and anthesis stages; I3, irrigate at regreen and

3 anthesis stages; 14 , irrigate at branch stage; 15 , irrigate at branch stage; I6, irrigate at anthesis stage; 17 , irrigate at regreen, branch and anthesis stages; $\mathrm{CK}$, no irrigation; 